\title{
Cytomegalovirus infection in native kidney biopsy
}

\author{
Raquel M Moreira1, Géssica SB Barbosa ${ }^{1 *}$, Cristiane B Dias ${ }^{1}$, Luis \\ $\mathrm{Yu}^{1}{ }^{1}$, Viktoria Woronik ${ }^{1}$ and Lívia B Cavalcante ${ }^{2}$
}

\begin{abstract}
${ }^{1}$ Nephrology Division, University of São Paulo School of Medicine, São Paulo-SP, Brazil ${ }^{2}$ Pathology Department, University of São Paulo School of Medicine, São Paulo-SP, Brazil
\end{abstract}

A 61-year-old Brazilian black woman consulted with a nephrologist due to proteinuria identified on a routine urine test. She has a personal history of thymoma resection five years ago, followed by multiple episodes of pulmonary infections including mycobacteriosis, recurrent mucocutaneous candidiasis, and paraneoplastic pemphigus. Physical examination showed no edema or hypertension and laboratory tests identified proteinuria of $2.43 \mathrm{~g} /$ day without hematuria, serum creatinine of $0.69 \mathrm{mg} / \mathrm{dl}$, urea $34 \mathrm{mg} / \mathrm{dl}$, serum albumin of $2.4 \mathrm{~g} / \mathrm{dl}$, hemoglobin $10.9 \mathrm{~g} / \mathrm{dl}$, platelets $292,000 / \mathrm{mm}^{3}$, leukocytes $4950 / \mathrm{mm}^{3}$, lymphocytes $594 /$ $\mathrm{mm}^{3}$ and neutrophils $3910 / \mathrm{mm}^{3}$. The hemolysis tests were negative and serum iron was low. Analysis of glicemia and serum lipids levels were normal as well as serum complement and imunoglobulins, except for an IgM level of $283 \mathrm{mg} /$ $\mathrm{dl}$ (normal values 40 to $230 \mathrm{mg} / \mathrm{dl}$ ) and undetectable IgE. Serologies for Syphilis, HIV, hepatitis B, C and antibodies for autoimmune diseases were negative.

A renal biopsy was performed. By light microscopy, the glomeruli showed a Focal and Segmental pattern of Glomerulosclerosis and proximal tubular epithelial cells revealed nuclear and cytoplasmic viral inclusions, typical of cytomegalovirus infection (Figure 1), which was confirmed by positive immunohistochemistry (Figure 2). Imunofluorescence revealed segmental and focal IgM, C3 and C1q with a "trapping" pattern.

Serum PCR for cytomegalovirus (CMV) was positive in low titers. Endoscopic biopsies of gastric ulcers also revealed CMV infection.

Cytomegalovirus infection is reported as a secondary cause of Focal Segmental Glomerulosclerosis (FSGS). However, the presence of cytomegalic inclusions is rarely found in native kidneys and they were reported more often in renal grafts. Therefore, this case is about a patient with Primary Immunodeficiency associated with thymoma, who

\section{More Information}

*Address for Correspondence: Géssica S.B. Barbosa, Nephrology Division, University of São Paulo School of Medicine, São Paulo-SP, Brazil, Email: gessica.barbosa@hc.fm.usp.br

Submitted: 15 December 2019

Approved: 16 December 2019

Published: 17 December 2019

How to cite this article: Moreira RM, Barbosa GSB, Dias CB, Yu L, Woronik V, et al. Cytomegalovirus infection in native kidney biopsy. J Clini Nephrol. 2019; 3: 186-186.

DOI: dx.doi.org/10.29328/journal.jcn.1001047

Copyright: () 2019 Moreira RM, et al. This is an open access article distributed under the Creative Commons Attribution License, which permits unrestricted use, distribution, and reproduction in any medium, provided the original work is properly cited.

(W) Check for updates

( $)$ OPEN ACCESS

developed disseminated CMV infection, with involvement of the native kidneys and development of proteinuria due to a secondary FSGS.

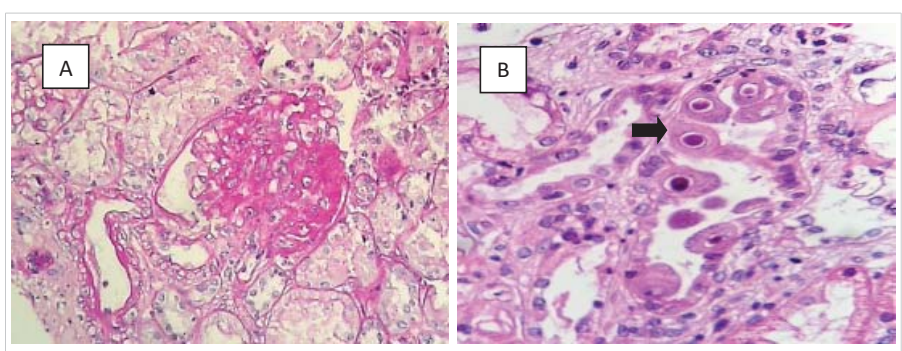

Figure 1: A glomerulus showing segmental sclerosis (A) (PAS, 200x). Cytomegalic inclusions in a proximal tubule, arrow (B) (HE, 400x).

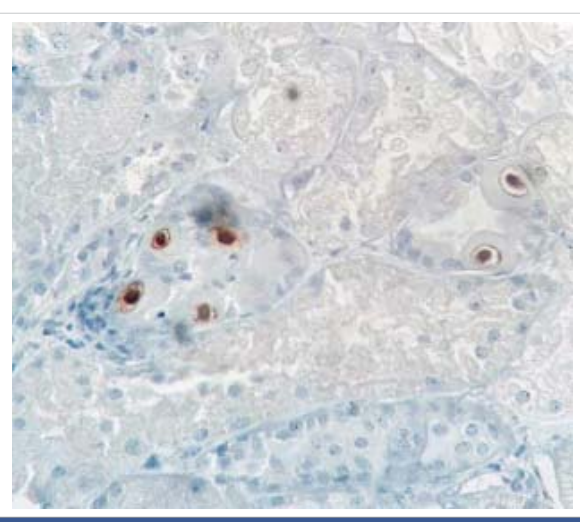

Figure 2: Tubular epithelial cells showing positive cytomegalovirus immunostaining (original magnification 400x). 